\title{
In Vitro Effects of Rabeprazole on Human Pylorus Tone
}

\author{
Necdet Fatih Yaşar, ${ }^{1 *}$ Erdal Polat, ${ }^{1}$ Mustafa Duman, ${ }^{1}$ Meltem Dağdelen, ${ }^{2}$ Mehmet Yalçın Günal, ${ }^{3}$ Orhan Uzun, ${ }^{1}$ Cebrail Akyüz, ${ }^{1}$ \\ Kıvanç Derya Peker $^{1}$ and Sinan Yol ${ }^{4}$ \\ ${ }^{1}$ Department of Gastrointestinal Surgery, Kartal Kosuyolu Training and Research Hospital, Istanbul, Turkey; ${ }^{2}$ Department of Pharmacology, \\ School of Medicine, Yeditepe University, Istanbul, Turkey; ${ }^{3}$ Department of Physiology, School of Medicine, Istanbul Medipol University, \\ Istanbul, Turkey; and ${ }^{4}$ Division of Gastrointestinal Surgery, Department of General Surgery, School of Medicine, Istanbul Medeniyet University, \\ Goztepe Training and Research Hospital, Istanbul, Turkey
}

\section{Background/Aims}

It has been reported that proton pump inhibitors induce relaxation in different types of smooth muscles. The aim of this study is to investigate in vitro effects of proton pump inhibitors on human pylorus muscle.

\section{Methods}

Pyloric sphincters were studied in 10 patients who were operated for stomach cancer. In isolated organ bath, control and response to rabeprazole were recorded following contraction with carbachol. During the treatment experiment, while distilled water was applied during the control experiment in every 5 minutes, rabeprazole was administered in every 5 minutes at doses of $10^{-6}, 10^{-5}, 10^{-4}$, and $10^{-3} \mathrm{M}$ respectively. Contraction frequencies, maximum contraction values and muscle tones were measured.

\section{Results}

The contraction frequencies in the control group were greater than the rabeprazole group in the second, third and fourth intervals while the maximum contraction values in the rabeprazole group were lower in the fourth interval. Even though muscles tones were not different in both groups during all intervals, it was remarkable that the muscle tone was significantly decreased in the rabeprazole group during the fourth interval compared to the first and second intervals.

Received: October 18, 2014 Revised: December 4, 2014 Accepted: December 14, 2014

(c) This is an Open Access article distributed under the terms of the Creative Commons Attribution Non-Commercial License (http://creativecommons. org/licenses/by-nc/3.0) which permits unrestricted non-commercial use, distribution, and reproduction in any medium, provided the original work is properly cited.

*Correspondence: Necdet Fatih Yaşar, MD

Department of Gastrointestinal Surgery Kartal Kosuyolu Yuksek Ihtisas Egitim ve Arastırma Hastanesi, Denizer Caddesi, Cevizli Kavsagı No:2 Cevizli/Kartal, Istanbul, Turkey

Tel: +90-533-7218406, Fax: +90-216-4596321, E-mail: nfyasar@gmail.com

Financial support: None.

\section{Conflicts of interest: None.}

Author contributions: Necdet Fatih Yaşar, Mustafa Duman, Erdal Polat, and Sinan Yol, study conception and design; Necdet Fatih Yaşar, Mustafa Duman, Erdal Polat, Orhan Uzun, Cebrail Akyüz, Kıvanç Derya Peker, and Sinan Yol, tissue collection; Necdet Fatih Yaşar, Meltem Dağdelen, Mustafa Duman, Mehmet Yalçın Günal, conduction of experiments; Necdet Fatih Yaşar, Mehmet Yalçın Günal, Meltem Dağdelen, data generation and analysis; Necdet Fatih Yaşar, Mustafa Duman, Erdal Polat, Orhan Uzun, Cebrail Akyüz, Kıvanç Derya Peker, and Sinan Yol, manuscript drafting; and all authors reviewed, commented upon, and approved the final submission.

ORCID: Necdet Fatih Yaşar, http://orcid.org/0000-0002-9751-2912; Erdal Polat, http://orcid.org/0000-0002-9463-9846; Mustafa Duman, http://orcid.org/0000-0002-0276-0543; Meltem Dağdelen, http://orcid.org/0000-0001-6786-9606; Mehmet Yalçın Günal, http://orcid.org/0000-0001-7702-2441; Orhan Uzun, http://orcid.org/0000-0001-7586-9075; Cebrail Akyüz, http://orcid.org/0000-0003-0917-9345; Kıvanç Derya Peker, http://orcid.org/0000-0002-8887-3505; Sinan Yol, http://orcid.org/0000-0001-7631-0935. 


\section{Conclusions}

In the present study, high doses of rabeprazole reduced contraction frequencies, maximum contraction values, and muscle tone of human pylorus.

(J Neurogastroenterol Motil 2015;21:217-221)

\section{Key Words}

Muscle tonus; Proton pump inhibitors; Pylorus; Rabeprazole

\section{Introduction}

It has been reported that proton pump inhibitors (PPIs) induce relaxation in smooth muscles of different types of tissues, such as artery, gallbladder, prostate, cavernous corpus, and myometrium. ${ }^{1-5}$ Two other studies, conducted after these previous studies, have shown that PPIs may also induce smooth muscle relaxation in lower esophageal sphincter in rat models. ${ }^{6,7}$ The effects of PPIs, which are commonly used in treatment of gastritis, gastric ulcer, and gastroesophageal reflux disease on pylorus, have yet to be investigated.

Pylorus is the most important control mechanism of the flow between the stomach and the intestines. In previous in vivo studies, it has been shown that physiological gastroduodenal flow and duodenogastric reflux occurs in a sequence and duodenogastric reflux occurs just before pyloric closure following gastroduodenal flow. ${ }^{8-10}$ Thus, the suspected cause of duodenogastric reflux or delayed gastric emptying is discoordination between pyloric and antral motor activities. ${ }^{811-13}$ Hence, any factor, which could interfere the cyclic contractions of the pylorus and antrum, may increase the reflux or slow down gastric emptying. ${ }^{8-10}$

The previous studies on gastroduodenal flow have suggested that PPIs not only decrease acid but also bile reflux, owing to its antisecretory effects. ${ }^{14-18}$ In the present study, we aimed to reveal the in vitro effects of PPIs on the contraction of human pylorus muscle, independent from anti-acid and antisecretory effects.

\section{Materials and Methods}

The experimental protocol was approved by the Ethical Committee of Yeditepe University Clinical Research Institute (No. 245). Tissues were obtained from patients undergoing gastric resection because of cancer. All patients were informed about the study prior to operation, approvals were obtained from all of the patients, and consents forms were signed by all patients. Ten patients were included in the study.

All tissues were found disease-free on macroscopic examination and the gastric resection margins, locating on the proximal site of pylorus, were evaluated on histological studies for confirmation. After removal, specimens were immediately cooled on ice and muscularis propria was dissected out. Upon isolation, tissues were placed in ice-cold, oxygenated Krebs solution $(\mathrm{NaCl}$, 118 mM; $\mathrm{NaHCO}_{3}, 25 \mathrm{mM}$; KCl, $4.6 \mathrm{mM} ; \mathrm{MgSO}_{4}, 1.2 \mathrm{mM}$; $\mathrm{NaH}_{2} \mathrm{PO}_{4}, 1.3 \mathrm{mM}$; Glukoz, $11 \mathrm{mM} ; \mathrm{CaCl}_{2}, 2.5 \mathrm{mM}$ ) in order to transport to the laboratory. Following the transportation, the sphincter muscle was set up as a ring in Kreb solution in the organ bath that contains Krebs solution which continuously bubbled with $5 \% \mathrm{CO}_{2}-95 \% \mathrm{O}_{2}$ at $37 \pm 0.5^{\circ} \mathrm{C}$. The tissues were tied to stainless steel hooks at one end to the organ bath; the other end was connected to a force transducer (FDT 05, May; COMMAT Iletisim $\mathrm{Co}$, Ankara, Turkey) under a approximate resting tension of $5 \mathrm{~g}$. Pyloric ring activities were recorded on an online computer via a 4-channel transducer data acquisition system (MP35; BIOPAC Systems Inc, Goleta, CA, USA) by using the software BSL PRO v 3.7 (BIOPAC Systems Inc), which also analyzed the data.

After 90 minutes equilibration period for stabilization, contractile response to carbachol was obtained by application of single dose of carbachol (Carbamylcholine chloride; Sigma Aldrich

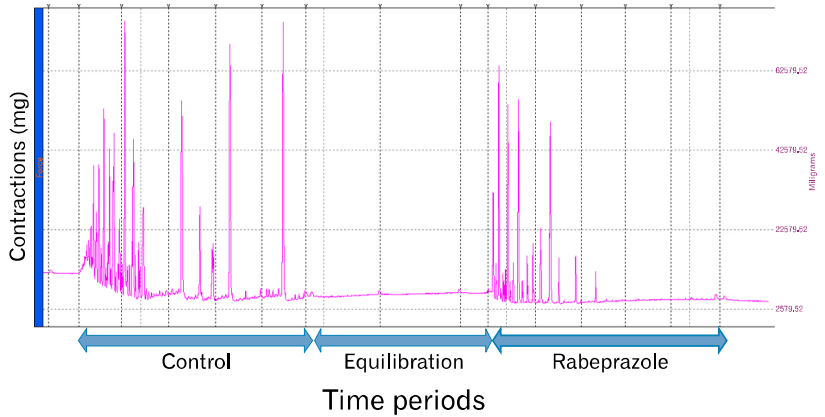

Figure 1. Pyloric ring activities were recorded on an online computer. 
Table. Time Intervals After Administration of Rabeprazole and Distilled Water

\begin{tabular}{ccc}
\hline Time intervals & Control group & Rabeprazole group \\
\hline First interval & 5-minute interval after first & administration of distilled water \\
Second interval & 5-minute interval after second & 5-minute interval after administration of \\
& administration of distilled water & Rabeprazole $\left(10^{-6} \mathrm{M}\right)$ \\
Third interval & 5 -minute interval after third & 5-minute interval after administration of \\
& administration of distilled water & Rabeprazole $\left(10^{-5} \mathrm{M}\right)$ \\
Forth interval & 5-minute interval after fourth & 5-minute interval after administration of \\
& administration of distilled water & Rabeprazole $\left(10^{-4} \mathrm{M}\right)$ \\
& & 5-minute interval after administration of \\
\hline
\end{tabular}

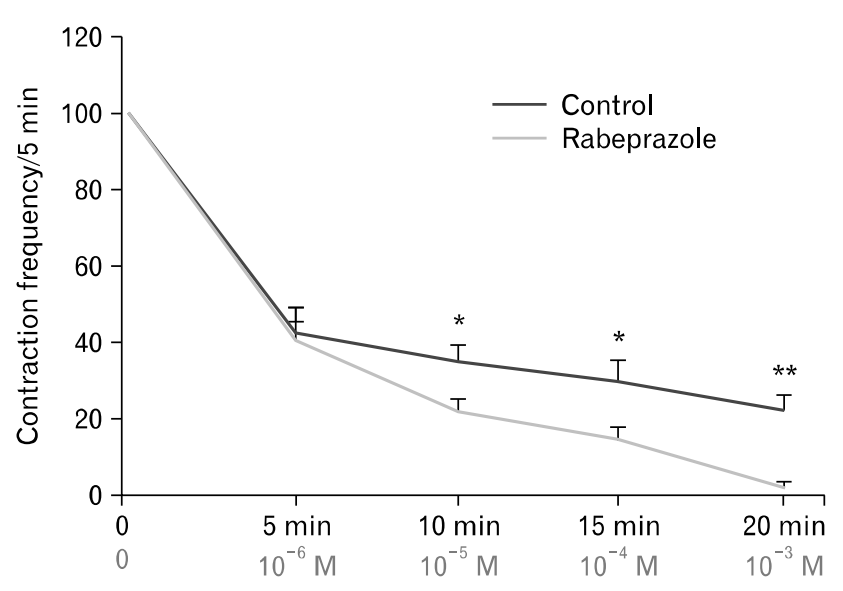

Time intervals and rabeprazole doses

Figure 2. Pyloric muscle contraction frequencies in 5-minute intervals as percentage relative to the contraction frequencies in the first 5 -minute interval. Control group versus rabeprazole group $\left({ }^{*} P<0.05,{ }^{* *} P<\right.$ $0.01)$.

Chemical Co, St. Louis, MO, USA) to have a final concentration of $10^{-5} \mathrm{M}$ in the organ bath. After the contractions reached a plateau, control experiments were run with only acidified distilled water added to the organ bath for four times with 5 minutes allotted between each. Following the control experiments and another 30 minutes equilibration period for stabilization, contractile response to carbachol was obtained by application of single dose of carbachol $\left(10^{-5} \mathrm{M}\right)$ for the second time. After the contractions reached a plateau, concentration-response relationships for rabeprazole (final organ bath concentrations of $10^{-6}, 10^{-5}, 10^{-4}$, and $10^{-3} \mathrm{M}$, with 5 minutes allotted between each dose) were obtained in a cumulative manner (Fig. 1).

For quantification, pyloric muscle responses were defined as contraction response $(\mathrm{mg})$, tone (integral value; the area under the activity line calculated by the software; mg-sn), and contraction frequencies (number of spikes) in 5-minute intervals. For standardisation, the responses in the 5-minute intervals after

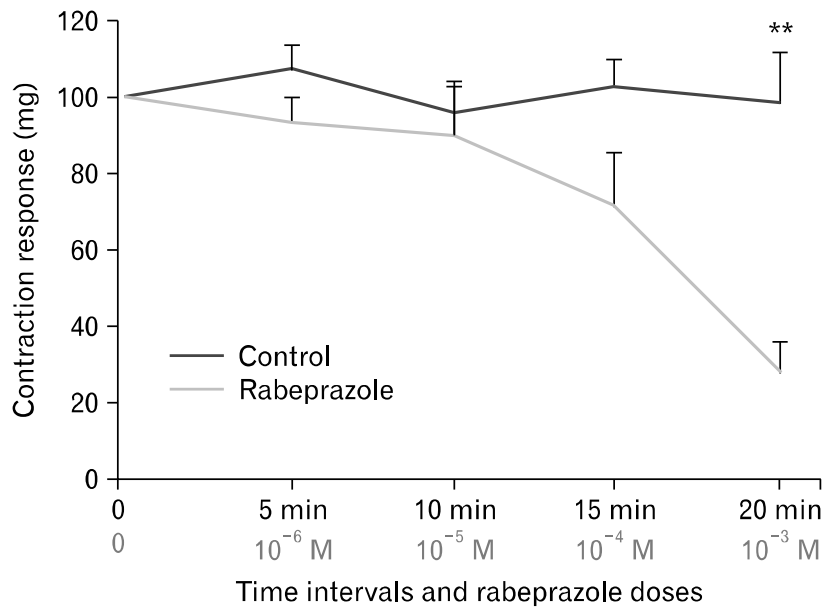

Figure 3. Pyloric muscle contraction response $(\mathrm{mg})$ in 5 -minute intervals as percentage relative to the contraction responses $(\mathrm{mg})$ in the first 5 -minute interval. Control group versus rabeprazole group $\left({ }^{* *} \mathrm{P}<\right.$ $0.01)$.

each application of carbachol were accepted as absolute values $(100 \%)$ and the following responses after administration of distilled water and rabeprazole were converted into percentages. Then, the data in each time interval were evaluated. Time intervals after administration of rabeprazole and distilled water were classed as presented in Table.

\section{Statistical Methods}

For statistical evaluation, analysis of variance (One way ANOVA) was performed with the SPSS program, windows version 18 (SPSS Inc, Chicago, IL, USA). Values of $P<0.05$ were considered as statistically significant.

\section{Results}

Contraction frequencies and maximum contraction values in the control and rabeprazole groups were not measured differently 


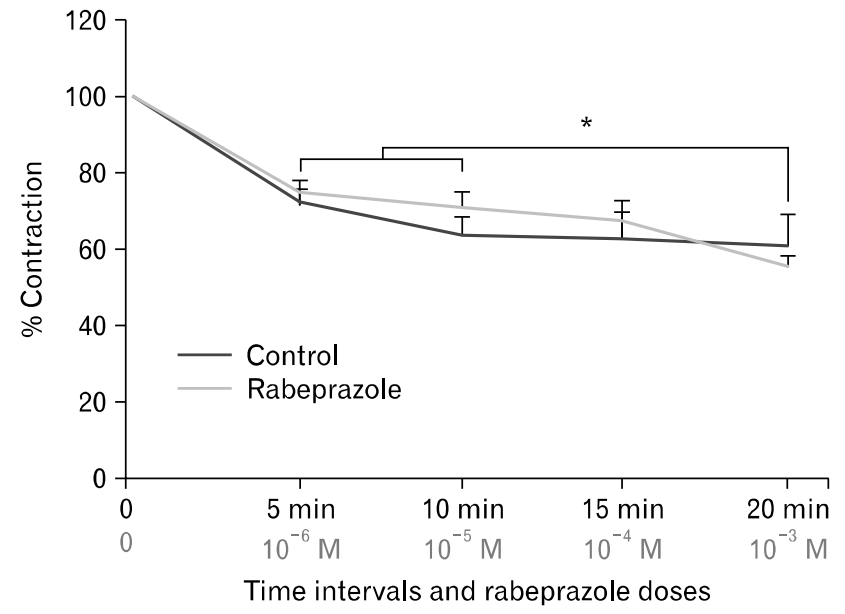

Figure 4. Pyloric muscle tones (integral values; mg-sn) in 5-minute intervals as percentage relative to the integral values in the first 5 -minute interval. The fourth 5-minute interval versus the first and second 5 -minute intervals in the rabeprazole group $\left({ }^{*} P<0.05\right)$.

in the first interval. The contraction frequencies in the control group were greater than the rabeprazole group in the second, third and fourth intervals (respectively; $P=0.032, P=0.034$, and $P=0.002$ ) (Fig. 2). Likewise, the difference between the maximum contraction values of the control group and the rabeprazole group became greater as the dose of rabeprazole was increased, and there was a significant difference in the fourth inter$\operatorname{val}(P=0.001)$ (Fig. 3). On the other hand, muscles tones were not measured differently between these 2 groups during all intervals $(P>0.05)$. However, it was remarkable that the muscle tone was significantly decreased in the rabeprazole group during the fourth interval compared to the first and second intervals $(P$ $=0.015$ and $P=0.048$, respectively) whereas there was not any difference measured in muscle tones of the control group between the time intervals (for all time intervals $P>0.05$ ) (Fig. 4).

\section{Discussion}

The main finding of our study is that high doses of rabeprazole may reduce contraction frequencies, maximum contraction values, and muscle tone of human pylorus.

Discoordination between pyloric and antral motor activities may cause either duodenogastric reflux or delayed gastric emtying. ${ }^{8,11-13}$ Even if pyloric and antral motor activities were studied in detail; the effects of PPIs which are the mainstay of treatment of gastritis, gastric ulcer, and gastroesophageal reflux disease, on human pyloric tonus have not been investigated yet.
While some of the studies on pyloric flow suggested that PPIs may decrease bile reflux due to antisecretory effects, ${ }^{14-18}$ others proposed that PPIs may actually increase duodenogastric reflux by slowing gastric emptying ${ }^{19-21}$ whereas in an another study, this relevance between PPIs and gastric emptying was disaffirmed. ${ }^{22}$ Yet, these studies are far from explaining the effects of PPIs on pylorus activities.

Relexant or inhibitory effects of PPIs at high doses were demonstrated on vascular precontracted smooth muscle, gallbladder, prostate, corpus cavernosum, myometrium, and lower esophageal sphincter. ${ }^{1-7}$ Therefore, in our study, we conducted the experiment from concentration of $10^{-6} \mathrm{M}$, which is actually about the Cmax of rabeprazole after single oral dosage of $20 \mathrm{mg}$, to $10^{-3} \mathrm{M} .^{23}$ The pathophysiological mechanism of these effects has yet to be identified but the most popular proposed model is the inhibition of voltage operated $\mathrm{Ca}^{2+}$ channels. In this study, we planned to observe the dose dependent effects of rabeprazole on the pylorus tone in the isolated human pylorus preparations, independent from any stimulation by acidity, paracrine hormones, and vagus nerve.

Studies showed that pyloric flow pulses last for a period of approximately 3 seconds whereas gastric contraction cycles last approximately 20 seconds. Retrograde flow through the pylorus occurs in one-third of the cases and characterized by a sequence of emptying-reflux-emptying. ${ }^{24}$ Duodenogastric reflux occurs just before pyloric closure, and hence, for much shorter episodes than gastroduodenal flow. ${ }^{8}$ As a result, the cyclic contractions play an important role in the maintenance of the sequence of duodenogastric reflux and gastroduodenal flow. In our study, contraction frequencies and maximum contraction values had a trend of reduction, starting with the therapeutic doses of rabeprazole and the difference became significant with high doses. Furthermore, we observed that even if there was not a significant difference between the groups, the reduction in the muscle tones of the rabeprazole group was remarkable as the dose of rabeprazole was increased.

As a conclusion, our findings suggested that rabeprazole caused no significant change in the contraction frequencies, maximum contraction values, and muscle tone of human pylorus at clinical dosage, whereas it reduced all of these 3 parameters at high doses. Further in vivo studies should be conducted to observe the effects of PPIs on pylorus when the initial treatment is switched to high dose PPI therapy in gastroesophageal reflux disease or gastric ulcer disease with refractory symptoms. 


\section{Acknowledgements}

The present study was supported by Yeditepe University. The authors are thankful to Ece Genc, Prof. Dr. for her invaluable mentorship.

\section{References}

1. Naseri E, Yenişehirli A. Proton pump inhibitors, omeprazole and lansoprazole induce relaxation of isolated human arteries. Eur J Pharmacol 2006;531:226-231.

2. Aydın C, Sarac B, Koyuncu A, Yildirim S, Sen M, Sarioglu Y. Relaxant effect of omeprazole and lansoprazole in guinea pig gallbladder muscle strips in vitro. J Gastroenterol 2003;38:765-771.

3. Bagcıvan I, Gökçe G, Ayan S, et al. Hydrogen-potassium ATPase inhibitors induce relaxation on rabbit prostatic strips in vitro. Int $\mathrm{J}$ Urol 2002;9:641-644; discussion 645.

4. Sarıglu Y, Yıldırım S, Utkan T, Yildirim MK, Uma S. Evidence of relaxant effect of omeprazole in rabbit corpus cavernosum in vitro. Life Sci 2000;66:1411-1421.

5. Yıldırım K, Sarıoğlu Y, Kaya T, Çetin A, Yıldırım S. Inhibitor effect of omeprazole in isolated human myometrial smooth muscle. Life Sci 2001;69:435-442.

6. Yurtsever AS, Pektaş M, Özkur M, Un I, Erenmemisoglu A, Buyukafsar K. Proton pump inhibitors omeprazole, lansoprazole and pantoprazole induce relaxation in the rat lower oesophageal sphincter. J Pharm Pharmacol 2011;63:1295-1300.

7. Duman M, Polat E, Özer M, et al. The effect of rabeprazole on LES tone in experimental rat model. J Invest Surg 2013;26:186-190.

8. Ramkumar D, Schulze KS. The pylorus. Neurogastroenterol Motil 2005;17(suppl 1):22-30.

9. Gowen GF. Spontaneous enterogastric reflux gastritis and esophagitis. Ann Surg 1985;201:170-175.

10. Hermans D, Sokal EM, Collard JM, Romagnoli R, Buts JP. Primary duodenogastric reflux in children and adolescents. Eur J Pediatr 2003;162:598-602.

11. Mearin F, Camilleri M, Malagelada JR. Pyloric dysfunction in diabetics with recurrent nausea and vomiting. Gastroenterology 1986; 90:1919-1925.
12. Indireshkumar $\mathrm{K}$, Brasseur JG, Faas $\mathrm{H}$, et al. Relative contributions of "pressure pump" and "peristaltic pump" to gastric emptying. Am J Physiol Gastrointest Liver Physiol 2000;278:G604-G616.

13. Anvari M, Yu P, Dent J, Jamieson GG. Role of antral intramural neural pathways in control of gastric emptying in the pig. J Physiol 1995;488(Pt 1):203-209.

14. Champion G, Richter JE, Vaezi MF, Singh S, Alexander R. Duodenogastroesophageal reflux: relationship to $\mathrm{pH}$ and importance in Barrett's esophagus. Gastroenterology 1994;107:747-754.

15. Marshall RE, Anggiansah A, Manifold DK, Owen WA, Owen WJ. Effect of omeprazole $20 \mathrm{mg}$ twice daily on duodenogastric and gastro-esophageal bile reflux in barrett's esophagus. Gut 1998;43:603606.

16. Stein HJ, Kauer WK, Feussner H, Siewert JR. Bile reflux in benign and malignant Barrett's esophagus: effect of medical acid suppression and Nissen fundoplication. J Gastrointest Surg 1998;2:333-341.

17. Menges M, Muller M, Zeitz M. Increased acid and bile reflux in Barrett's esophagus compared to reflux esophagitis, and effect of proton pump inhibitor therapy. Am J Gastroenterol 2001;96:331-337.

18. Chen H, Li X, Ge Z, Gao Y, Chen X, Cui Y. Rabeprazole combined with hydrotalcite is effective for patients with bile reflux gastritis after cholecystectomy. Can J Gastroenterol 2010;24:197-201.

19. Rasmussen L, Oster-Jorgensen E, Qvist N, Kraglund K, Hovendal C, Pedersen SA. Short report: a double-blind placebo-controlled trial of omeprazole on characteristics of gastric emptying in healthy subjects. Aliment Pharmacol Ther 1991;5:85-89.

20. Hongo M, Lin YF, Ujiie H. Acid suppression by omeprazole inhibits gastric emptying in normal subjects. Gastroenterology 1996; 96:A218.

21. Benini L, Castellani G, Bardelli E, et al. Omeprazole causes delay in gastric emptying of meals. Dig Dis Sci 1996;41:469-474.

22. Horowitz M, Hetzel DJ, Buckle PJ, Chatterton BE, Shearman DJ. The effect of omeprazole on gastric emptying in patients with duodenal ulcer disease. Br J Clin Pharmacol 1984;18:791-794.

23. Niioka T, Uno T, Yasui-Furukori N, Shimizu M, Sugawara K, Tateishi T. Identification of the time-point which gives a plasma rabeprazole concentration that adequately reflects the area under the concentration-time curve. Eur J Clin Pharmacol 2006;62:855-861.

24. King PM, Adam RD, Pryde A, McDicken WN, Heading RC. Relationships of human antroduodenal motility and transpyloric fluid movement: non-invasive observations with real-time ultrasound. Gut 1984;25:1384-1391. 